\title{
Resolution of Cutaneous Sarcoidosis Following Topical Application of Ganoderma lucidum (Reishi Mushroom)
}

\author{
Gulcan Saylam Kurtipek · Arzu Ataseven · Ercan Kurtipek • \\ İlknur Kucukosmanoglu • Mustafa Rasid Toksoz
}

To view enhanced content go to www.dermtherapy-open.com Received: January 4, 2016 / Published online: February 11, 2016

(C) The Author(s) 2016. This article is published with open access at Springerlink.com

\section{ABSTRACT}

Ganoderma lucidum (reishi mushroom) has been used in traditional Chinese and Japanese medicine as a herbal remedy for over 2000 years. Studies have shown that G. lucidum has anti-allergic, anti-oxidant, anti-tumor, anti-viral, and anti-inflammatory properties. A review of the literature revealed that there were no studies examining the use of G. lucidum for the treatment of skin diseases. Here, we report the case of a 44-year-old male patient who used soap enriched with G. lucidum and goat's milk for 3 days in treating annular cutaneous

G. Saylam Kurtipek $(\bowtie) \cdot$ A. Ataseven

Department of Dermatology, Konya Training and

Research Hospital, Konya, Turkey

e-mail: gsaylamkurtipek@yahoo.com

E. Kurtipek

Department of Chest Disease, Konya Training and

Research Hospital, Konya, Turkey

İ. Kucukosmanoglu

Department of Pathology, Konya Training and

Research Hospital, Konya, Turkey

M. R. Toksoz ( $\square)$

Department of Plastic, Reconstructive and Aesthetic

Surgery, Konya Training and Research Hospital,

Konya, Turkey

e-mail: drmrtoksoz@gmail.com sarcoidosis. The patient showed almost complete regression of the lesions.

Keywords: Annular cutaneous sarcoidosis; Ganoderma lucidum; Topical treatment

\section{INTRODUCTION}

Sarcoidosis is a systemic disease characterized by non-caseating granulomas with an unknown etiology. It primarily involves the pulmonary and lymphatic systems, but it can also involve organs such as the skin, eyes, spleen, bones, joints, and parotid glands. Skin involvement is seen in approximately one-third of patients [1]. Ganoderma lucidum has been used in traditional Chinese and Japanese medicine as a herbal remedy for over 2000 years due to its immunogenic effects [12]. Modern studies have also reported on the anti-allergic, anti-androgenic, anti-hyperglycemic, anti-oxidant, anti-tumor, anti-viral, and anti-inflammatory properties of G. lucidum [2-5].

The authors could find no data regarding the use of G. lucidum for the treatment of any skin 
diseases in the literature. Here, we report the case of a 44-year-old male patient with annular cutaneous sarcoidosis of the scalp treated with a soap containing G. lucidum for 3 days who showed almost complete regression of the lesions.

\section{CASE REPORT}

Informed consent was obtained from the patient for being included in this case report and for publication of the accompanying images.

A 44-year-old male patient presented to our outpatient clinic for multiple infiltrated plaques on his scalp for 4 years. A dermatological examination showed multiple plaque lesions of annular erythema with central atrophy and raised borders (Fig. 1). An inflammatory and

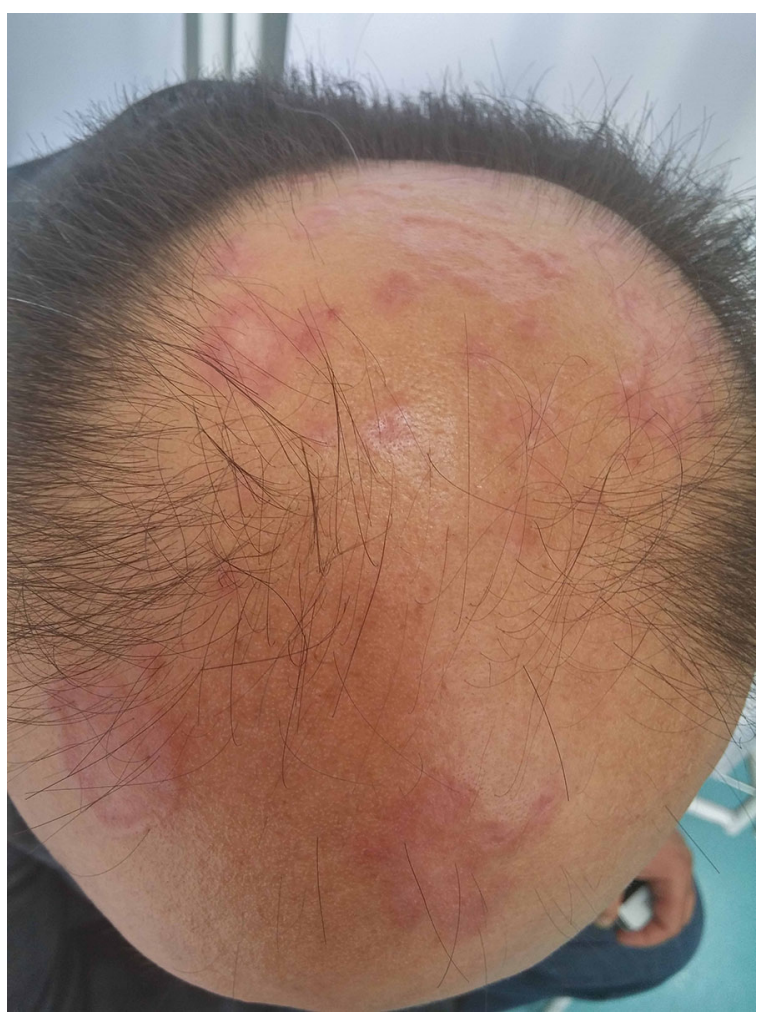

Fig. 1 Multiple plaque lesions of annular erythema with central atrophy and raised borders on the scalp granulomatous reaction in the dermis of the skin, originating beneath the surface epithelium (Fig. 2a), and granulomas consisting of epithelioid histiocytes and multinucleated giant cells (Fig. 2b) were detected during the histopathological assessment of the diagnostic biopsy specimen. A systemic screening was performed when available evidence supported a diagnosis of cutaneous sarcoidosis. The chest $\mathrm{X}$-ray showed bilateral hilar enlargement, and the computed thoracic tomography revealed many lymph nodes in the perivascular region, paratracheal region, subcarinal region, and in both hilar regions, where the short axis of the
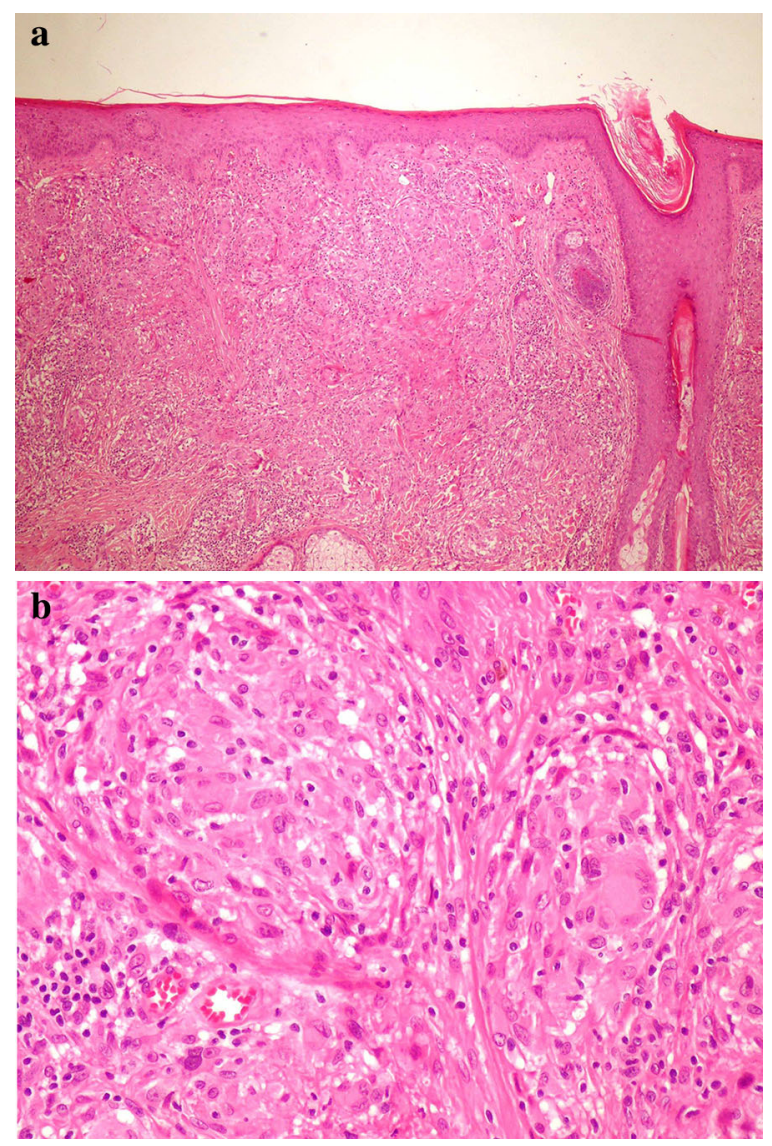

Fig. 2 a Histopathological assessment revealed an inflammatory and granulomatous reaction in the dermis of the skin, originating beneath the surface epithelium (HE $\times 100)$. $\mathbf{b}$ Granulomas consisting of epithelioid histiocytes and multinucleated giant cells were detected $(\mathrm{HE} \times 400)$ 
largest lymph node in the right hilus reached up to $1.4 \mathrm{~cm}$ in diameter. The patient was diagnosed with cutaneous sarcoidosis based on the typical lung involvement, elevated angiotensin-converting enzyme levels, and histopathologic findings.

After designing a treatment plan during a control visit, the patient reported that they had found and used a solid soap which contained $G$. lucidum and goat's milk from a herbal shop (GanoSoap $^{\circledR}$, Gano Exel Industries Sdn. Bhd., Malaysia). The patient indicated that they kept the soap foam on the lesion for $1 \mathrm{~h}$, and then rinsed it and repeated the procedure for a total of 3 days. A dermatological examination showed that almost all of the lesions had disappeared (Fig. 3). After 6 months, the lesions recurred and the patient applied the same soap again. The lesions disappeared

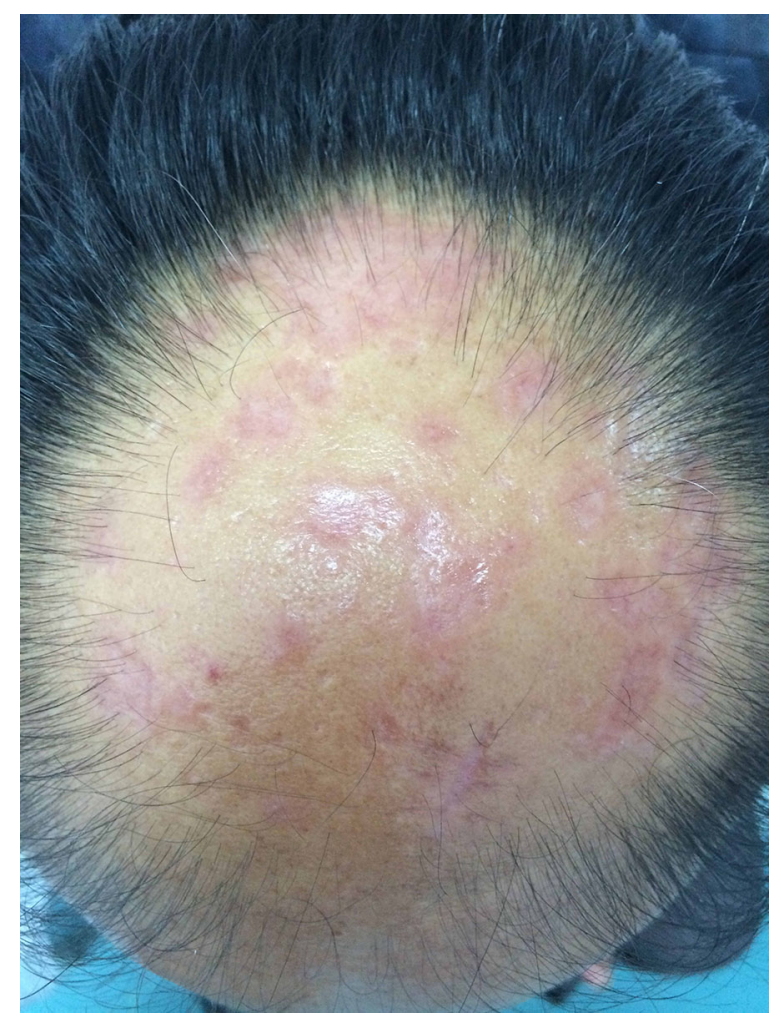

Fig. 3 The lesions almost disappeared after using topical Ganoderma lucidum within a week and the scalp lesions are in remission.

\section{DISCUSSION}

The cutaneous involvement in sarcoidosis is classified as specific and non-specific skin lesions. The most common specific skin lesions include infiltrated plaques, maculopapular eruptions, infiltration of old scars, lupus pernio, and subcutaneous sarcoidosis. The non-specific skin lesions are often erythema nodosum, erythema multiforme, calcification, and prurigo. In histopathological analyses, specific lesions are characterized by typical granulomas while non-specific lesions show a non-diagnostic inflammatory reaction. Sarcoidosis should not be overlooked by dermatology polyclinics since cutaneous involvement can manifest as a first sign of the disease in some cases. Our patient initially presented with skin lesions, and lung involvement was detected following a thorough examination $[6,7]$.

Reishi or lingzhi mushroom (G. lucidum) is a species of the Polyporaceae family of fungi which has been used as a remedy in traditional Chinese, Japanese, and Korean medicine in extract fluid. Reishi mushroom is not edible. It usually grows on the stumps of oak and plum trees over a period of approximately 9 months. Several classes of bioactive substances, such as triterpenoids, polysaccharides, nucleosides, sterols, and alkaloids, have been isolated from G. lucidum [8]. Both in vitro and in vivo studies with $G$. lucidum have demonstrated that G.lucidum polysaccharides have anti-tumor activity through their immunomodulatory, anti-angiogenic, and cytotoxic effects. However, there are many questions that need 
to be answered before it is accepted and used as an anti-tumor agent [9-11].

\section{CONCLUSIONS}

Ganoderma lucidum has not been used so far in dermatological diseases. Regression of skin lesions in our patient as early as 3 days supports the anti-inflammatory property of G. lucidum. G. lucidum may be a potential treatment option for the management of skin diseases with cutaneous sarcoidosis and inflammation in the future.

\section{ACKNOWLEDGMENTS}

No funding or sponsorship was received for this study or publication of this article. All named authors meet the International Committee of Medical Journal Editors (ICMJE) criteria for authorship for this manuscript, take responsibility for the integrity of the work as a whole, and have given final approval for the version to be published.

Disclosures. Gulcan Saylam Kurtipek, Arzu Ataseven, Ercan Kurtipek, İlknur Kucukosmanoglu, and Mustafa Rasid Toksoz have nothing to disclose.

\section{Compliance with Ethics}

Guidelines. Informed consent was obtained from the patient for being included in this case report and for publication of the accompanying images.

Open Access. This article is distributed under the terms of the Creative Commons AttributionNonCommercial 4.0 International License (http://creativecommons.org/licenses/by-nc/4. $0 /$ ), which permits any noncommercial use, distribution, and reproduction in any medium, provided you give appropriate credit to the original author(s) and the source, provide a link to the Creative Commons license, and indicate if changes were made.

\section{REFERENCES}

1. Moche MJ, Glassman SJ, Modi D, Grayson W. Cutaneous annular sarcoidosis developing on a background of exogenous ochronosis: a report of two cases and review of the literature. Clin Exp Dermatol. 2010;35:399-402.

2. Sanodiya BS, Thakur GS, Baghel RK, Prasad GB, Bisen PS. Ganoderma lucidum: a potent pharmacological macrofungus. Curr Pharm Biotechnol. 2009;10:717-42.

3. Chen HS, Tsai YF, Lin S, et al. Studies on the immuno-modulating and anti-tumor activities of Ganoderma lucidum (Reishi) polysaccharides. Bioorg Med Chem. 2004;12:5595-601.

4. Li YQ, Wang SF. Anti-hepatitis B activities of ganoderic acid from Ganoderma lucidum. Biotechnol Lett. 2006;28:837-41.

5. Eo SK, Kim YS, Lee CK, Han SS. Possible mode of antiviral activity of acidic protein bound polysaccharide isolated from Ganoderma lucidum on herpes simplex viruses. J Ethnopharmacol. 2000;72:475-81.

6. Krasowska D, Schwartz RA, Wojnowska D, Maćkiewicz B, Czelej D. Polymorphous cutaneous and chronic multisystem sarcoidosis. Acta Dermatovenerol Alp Pannonica Adriat. 2008;17:26-30.

7. Cather JC, Cohen PR. Ichthyosiform sarcoidosis. J Am Acad Dermatol. 1999;40:862-5.

8. Bao X, Liu C, Fang J, Li X. Structural and immunological studies of a major polysaccharide from spores of Ganoderma lucidum. Carbohydr Res. 2001;332:67-74.

9. Kabir Y, Kimura S, Tamura T. Dietary effect of Ganoderma lucidum mushroom on blood pressure and lipid levels in spontaneously hypertensive rats. J Nutr Sci Vitaminol. 1988;34:433-8.

10. Seto SW, Lam TY, Tam HL, et al. Novel hypoglycemic effects of Ganoderma lucidum 
water-extract in obese/diabetic $(+\mathrm{db} /+\mathrm{db})$ mice. Phytomedicine. 2009;16:426-36.

11. Harhaji Trajkovic LM, Mijatovic SA, Maksimovic-Ivanic DD, et al. Anticancer properties of Ganoderma lucidum methanol extracts in vitro and in vivo. Nutr Cancer. 2009;61:696-707.
12. Batra P, Sharma AK, Khajuria R. Probing Lingzhi or Reishi medicinal mushroom Ganoderma lucidum (higher Basidiomycetes): a bitter mushroom with amazing health benefits. Int J Med Mushrooms. 2013;15(2):127-43. 